\title{
Rock-magnetism and ore microscopy of the magnetite-apatite ore deposit from Cerro de Mercado, Mexico
}

\author{
L. M. Alva-Valdivia ${ }^{1}$, A. Goguitchaichvili ${ }^{1}$, J. Urrutia-Fucugauchi ${ }^{1}$, C. Caballero-Miranda ${ }^{1}$, and W. Vivallo ${ }^{2}$ \\ ${ }^{1}$ Instituto de Geofísica, Universidad Nacional Autónoma de México, Del. Coyoacan 04510 D. F., México \\ ${ }^{2}$ Servicio Nacional de Geología y Minería, Chile
}

(Received July 14, 2000; Revised December 19, 2000; Accepted January 24, 2001)

\begin{abstract}
Rock-magnetic and microscopic studies of the iron ores and associated igneous rocks in the Cerro de Mercado, Mexico, were carried out to determine the magnetic mineralogy and origin of natural remanent magnetization (NRM), related to the thermo-chemical processes due to hydrothermalism. Chemical remanent magnetization (CRM) seems to be present in most of investigated ore and wall rock samples, replacing completely or partially an original thermoremanent magnetization (TRM). Magnetite (or Ti-poor titanomagnetite) and hematite are commonly found in the ores. Although hematite may carry a stable CRM, no secondary components are detected above $580^{\circ}$, which probably attests that oxidation occurred soon enough after the extrusion and cooling of the ore-bearing magma. NRM polarities for most of the studied units are reverse. There is some scatter in the cleaned remanence directions of the ores, which may result from physical movement of the ores during faulting or mining, or from perturbation of the ambient field during remanence acquisition by inhomogeneous internal fields within these strongly magnetic ore deposits. The microscopy study under reflected light shows that the magnetic carriers are mainly titanomagnetite, with significant amounts of ilmenite-hematite minerals, and goethite-limonite resulting from alteration processes. Magmatic titanomagnetites, which are found in igneous rocks, show trellis, sandwich, and composite textures, which are compatible with high temperature (deuteric) oxy-exsolution processes. Hydrothermal alteration in ore deposits is mainly indicated by martitization in oxide minerals. Grain sizes range from a few microns to $>100$ $\mu \mathrm{m}$, and possible magnetic state from single to multidomain, in agreement with hysteresis measurements. Thermal spectra, continuous susceptibility measurements, and IRM (isothermal remanent magnetization) acquisition suggest a predominance of spinels as magnetic carriers, most probably titanomagnetites with low-Ti content. For quantitative modeling of the aeromagnetic anomalies, we used data on bulk susceptibility and natural remanent intensity for quantifying the relative contributions of induced and remanent magnetization components and allow a better control of the geometry of source bodies. The position and geometry of this magnetic source are shown as an ENE-striking tabular body, steeply inclined $\left(75^{\circ}\right)$ to the south.
\end{abstract}

\section{Introduction}

Paleomagnetic studies depend directly on the recording system, which comprises ferrimagnetic minerals, particularly Fe-Ti oxides, and Fe hydroxides and sulfides. Rock magnetic techniques can characterize the composition, grain size, domain state and other properties of the magnetic minerals that control the paleomagnetic stability and influence the paleomagnetic record. Paleomagnetic techniques have not been routinely applied to ore deposits, because it has been considered that the coarse-grained textures of many ores would be a source of low magnetic stability. On the other hand, a natural field of research using rock magnetism is in exploration and exploitation of iron-ore deposits, where the magnetic methods of exploration are widely applied and of highest resolution in time and space (Grant, 1985). In this context, the relatively low number of rock-magnetic studies in iron-ore deposits (e.g., Ehrlich et al., 1969; Leslie, 1975; Symons et al., 1981; Clark and Schmidt, 1993; Alva-Valdivia

Copy right $(\mathrm{C})$ The Society of Geomagnetism and Earth, Planetary and Space Sciences (SGEPSS); The Seismological Society of Japan; The Volcanological Society of Japan; The Geodetic Society of Japan; The Japanese Society for Planetary Sciences. et al., 1996; Alva-Valdivia and Urrutia-Fucugauchi, 1998) is notable.

A potential difficulty in applying paleomagnetic techniques to the study of ore deposits is the susceptibility of ores to chemical alteration. This is especially important for iron ores, owing to the high concentration of reduced iron, and of massive sulphide ores, which are prone to supergene oxidation and even to spontaneous combustion. Thus, chemical remanent magnetization (CRM) should be a common occurrence in ore deposits. Rock-magnetism seems a suitable tool for investigating Mexican ore deposits. Assuming that the ores were initially lava flows of magnetite, they probably cooled rapidly and acquired a stable thermoremanent magnetization (TRM). Several kinds of thermo-chemical processes, which usually occur after emplacement of volcanic material, may result in recrystallization of opaque minerals. Consequently, a TRM may be partially or completely replaced by CRM. We carried out a detailed rock-magnetic study of Cerro de Mercado ore deposits, one of the most important $\mathrm{Fe}$-ore deposits in Mexico, in order to define magnetic mineralogy and remanence characteristics related to postemplacement thermo-chemical processes. Rock-magnetic 

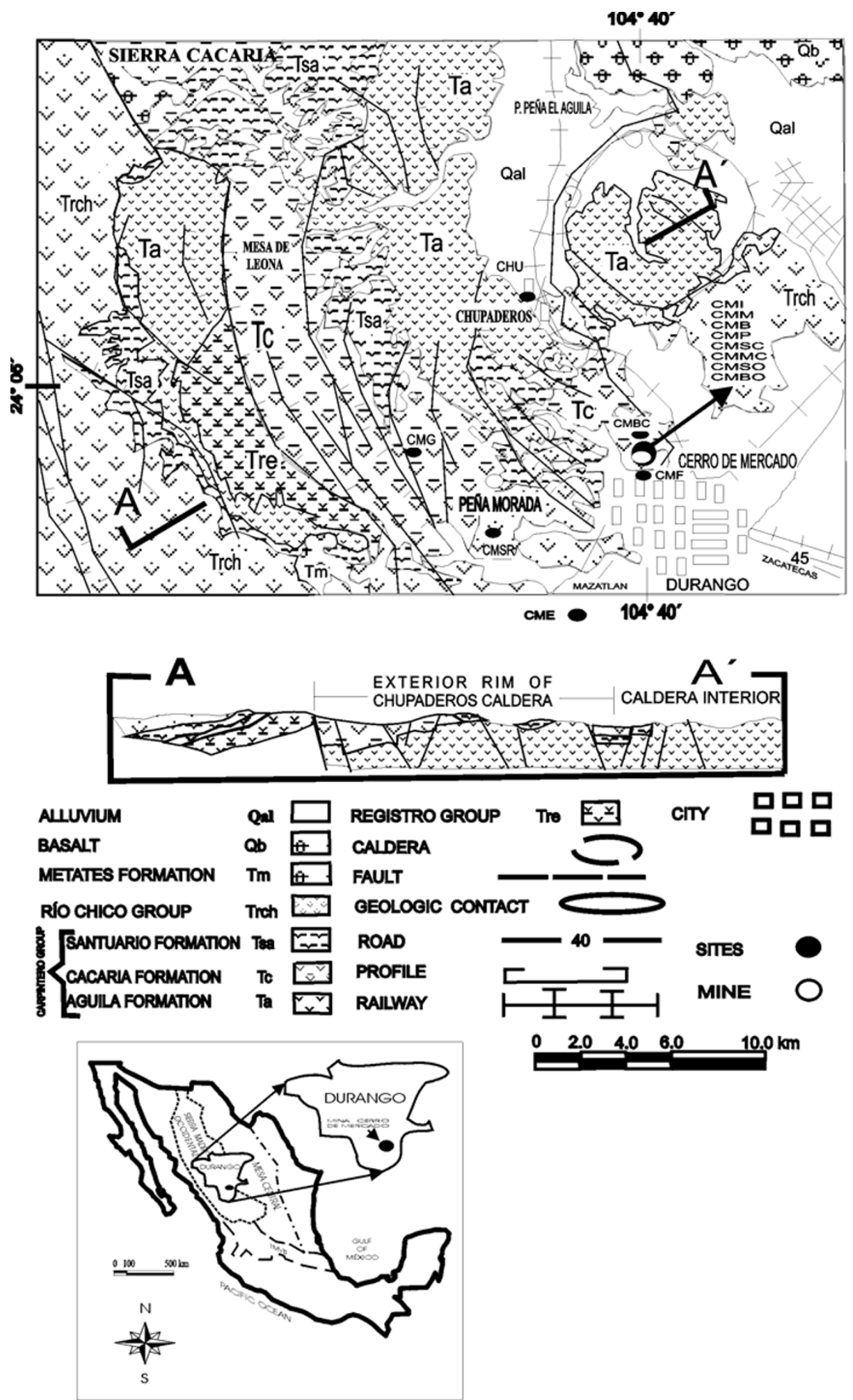

Fig. 1. Simplified geologic map of the regional study area showing the location of the iron-ore mining district Cerro de Mercado. Modified from Consejo de Recursos Minerales (1985).

parameters were successfully used for modeling the aeromagnetic anomaly, by providing adequate control of the geometry of source bodies.

The Cerro de Mercado iron-ore deposit is located in the northern sector of Durango city, Mexico (Fig. 1). Conflicting theories of replacement and magmatic injection for the origin of the iron ore, along with excellent but rapidly disappearing exposures, make Cerro de Mercado an ideal Fe-ore deposit to carry out an interdisciplinary project involving geochemistry, stable isotopes, and advanced mineralogy in order to clarify the controversy about the origin (this is a research project in progress whose results will be published soon). In all 

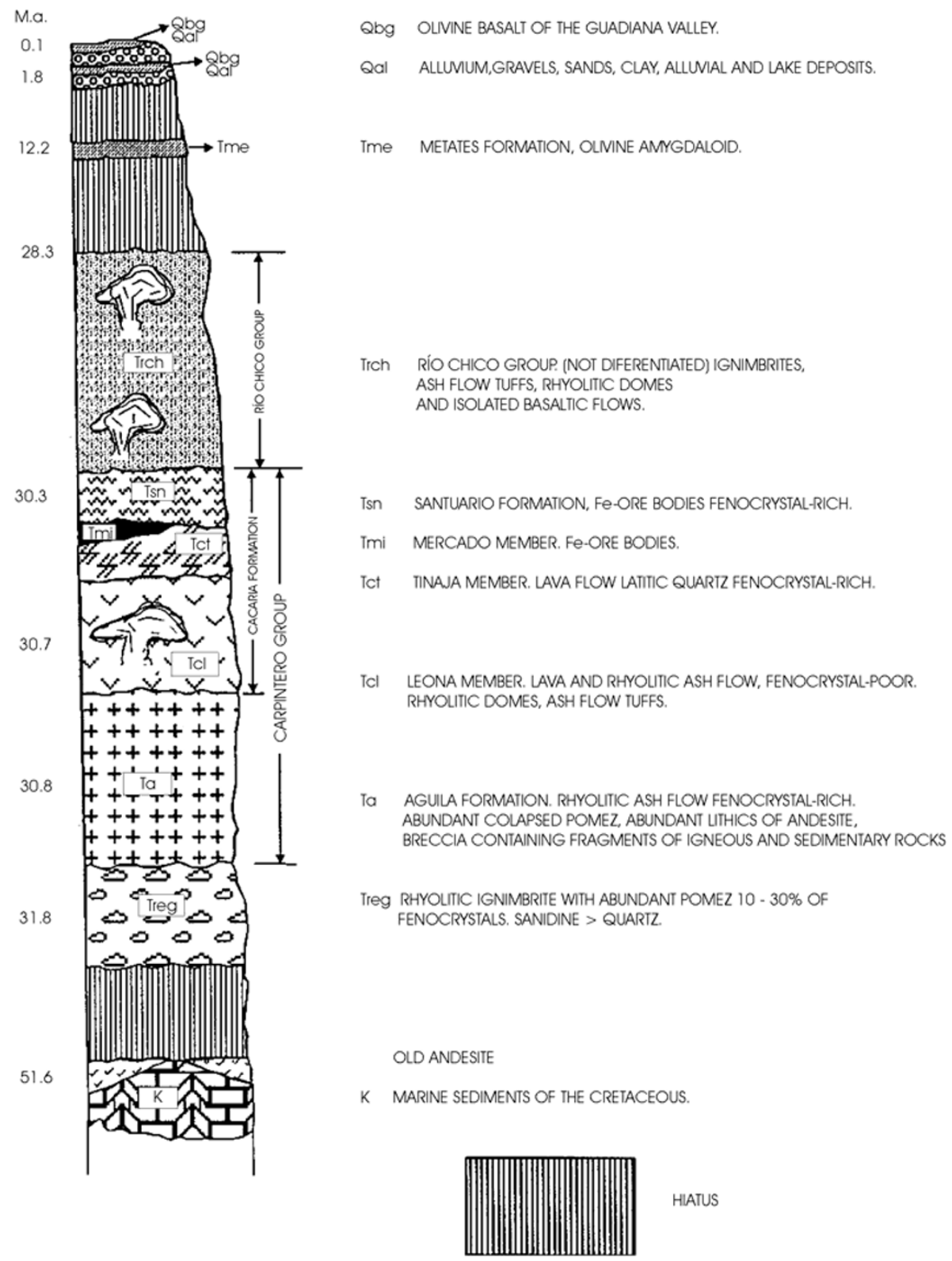

Fig. 2. Stratigraphic sequence indicating age and geologic formations.

genetic models, the ores are interpreted as having originally consisted of magnetite, which has oxidized to martite, i.e., hematite pseudomorphous after magnetite.

A fluid inclusion study in fluorapatite from oxidized ore and altered footwall rhyolite indicates that the emplacement of the apatite accompanied a hydrothermal event of moderate temperature (greater than $350^{\circ} \mathrm{C}$ ) at a crustal depth in excess of $400 \mathrm{~m}$ (Leslie, 1975). The oxidation of the iron ores and the alteration of the footwall are interpreted as having taken place during the thermal event. This event implies the presence of CRM developed during oxidation. Thus, Cerro de Mercado affords an opportunity to investigate a hydrothermal event and its effects on the magnetic properties of the iron ores and host rocks, which is the done in this study.

Besides, we investigate the magnetic characteristics which help to constrain the quantitative interpretation by using measured magnetic properties, leaving size, shape, and depth of possible source bodies as free variables to fit the observed magnetic anomaly.

\section{Geology and Mineralization}

Since the 70s several researchers have made efforts to define the stratigraphy and tectonics of the Durango City area (Fig. 1) (Swanson, 1974; Lyons, 1975, 1988; McDowell and Keiser, 1977; Labarthe et al., 1990). Below we provide a summary of the mining district based on these works.

The iron deposits of this area were formed by subaerial volcanic processes during a hiatus between two major eruptive cycles emanating from the $30 \mathrm{Ma}$ Chupaderos caldera. The first major eruption of the Chupaderos caldera produced the hematitic rhyolitic ash-flow tuffs of the Aguila Formation. During resurgent doming of the caldera floor, the Cacaria Formation filled the moat around the central dome of the Chupaderos caldera. The lower Cacaria, the Leona mem- 
ber, consists of extensive rhyolite flow domes, flows, and volcanoclastic tuffs. The various facies of the Mercado Iron Member were deposited on the surface of the Leona Member as well as on the resurgently domed Aguila Formation. A minor quartz latite extrusive activity was concurrent with the eruption of the Mercado Iron Member. Both units preceded the eruption of a second major welded tuff, the Santuario Formation, which incorporated fragments of iron oxides in its base. The Durango volcanic sequence (Fig. 2) began with isolated andesitic flows at 51.6 Ma going through ash flow tuffs, rhyolites, quartz-latite flows, olivine basalts, and Quaternary basalts of the Guadiana valley at $0.1 \mathrm{Ma}$.

The Cerro de Mercado iron deposit consists of four facies: (1) a martite facies - massive to layered, coarsely crystalline, porous martite (hematite pseudomorphous after magnetite) at the base, with dike and pluglike extensions downward into the underlying rhyolite, (2) a sandy magnetite facies - unconsolidated, laminated, fine grained sandy magnetite above the martite, (3) a blocky facies-unlaminated sandy magnetite matrix, mixed with blocks of the overlying quartz latite flow, and (4) a mixed iron oxide facies-tabular and dikelike bodies of fine-grained magnetite-hematite intergrowths that cut and cap the sequence.

Geologic relationships suggest that the iron deposits formed as a result of a variety of subaerial volcanic processes. The main deposit at Cerro de Mercado apparently resulted from the eruption of an iron-rich magma with abundant volatiles of fluorine, chlorine, carbon dioxide, and water. Sheeted flows and flow breccias formed a volcanic dome above an intrusive feeder system. Iron oxides crystallized as magnetite, with abundant, clear, yellow-green apatite crystals forming concurrently in gas cavities and open breccias. Large volumes of halogen-rich gases streamed up through the iron oxide flows and oxidized the magnetite to hematite (martite) and redeposited the iron leached from the nowporous martite as laminated sandy magnetite in an extensive fumarolic blanket. During the later stages of the cooling process, a quartz latite dike intruded and flowed out over the deposit. Basal blocky flow breccias of the quartz latite mixed with and disrupted the finely laminated texture of much of the sandy magnetite, creating extensive quartz latite breccias with a sandy magnetite matrix. Late-stage hematitemagnetite dikes cut the entire system and fed flows, which capped the mound. In the surrounding of Cerro de Mercado large volumes of iron-rich vapor explosively vented into the atmosphere and crystallized as fine-grained hematite dust, which formed an ash-like blanket covering a large area. Flow textures, interlayered with the ash-like hematite, at the base of Peña Morada deposit, suggests actual flows or welded tuff flows of this material. The occurrence of a maximum thickness of the ash-like hematite at Peña Morada indicates its proximity to a vent. At Cerro de Mercado the volatile-rich nature of the system resulted in extensive replacement of the underlying pre-mineralization rhyolites by a mixture of magnetite and pyroxene. Post-mineralization tuffs overlying the iron ore contain iron oxide fragments at their bases with no alteration.

Comparison of Cerro de Mercado with other apatite-bearing, low titanium iron deposits associated with silicic volcanic systems suggests that this volcanogenic model may be applicable to many of them. The volcanic environment produces a mixture of intrusive, replacement, and sedimentary textures, which may explain the heated debates, found in the literature over the origin of many of these deposits. These systems include the Precambrian Kiruna deposits of Sweden, the central Missouri iron deposits, and the Olympic Dam deposit; the Jurassic deposits of northeast Nevada; and the Tertiary deposits of Mexico and Chile (e.g., Bookstrom, 1977; Frietsch, 1978; Nystrom and Henriquez, 1994; Travisany et al., 1995).

\section{Sampling and Methods of Study}

We collected 84 drill-core samples from 14 sites of hostrocks and $\mathrm{Fe}$-ore from the cut exposures in the Chupaderos caldera area and Cerro de Mercado deposit (Fig. 1). Five to nine cores were taken at each site with a portable gasolinepowered drill, and oriented with an inclinometer and magnetic compass (after testing that it was not affected by the remanent magnetization of the outcrop).

Remanent magnetization was measured with a Molspin spinner magnetometer. Separation of secondary magnetization components from the characteristic component was accomplished by thermal demagnetization up to $680^{\circ} \mathrm{C}$ using a non-inductive Schonstedt furnace. Room-temperature low-field magnetic susceptibility $k$ was measured with a MS2 Bartington susceptibility meter. Continuous susceptibility measurements (i.e., $k$-T curves) were obtained using a Highmoor and a Bartington instrument. Isothermal remanent magnetization (IRM) acquisition curves with 10-12 steps to a maximum field of $600 \mathrm{mT}$ were obtained with a pulse magnetizer in selected samples, and demagnetization of the IRMs were done by step-wise alternating field (AF) using a Schonstedt demagnetization apparatus; using 8-14 steps up to a maximum field of $230 \mathrm{mT}$.

Magnetic hysteresis loops were measured with an alternating gradient force magnetometer, 'MicroMag'. IRM acquisition and DC back-field demagnetization curves were also acquired with this instrument. Opaque minerals were examined under reflected light to determine composition, texture, oxidation state, and degree of alteration.

\section{Microscopy}

\subsection{Background}

Petrographic and opaque mineral study was done with an ore microscope using thin and polished sections, and oil immersion, for a sample from each site. Direct observation of opaque minerals may assist in estimating the origin of magnetization, because we still have no clear magnetic evidence to distinguish between TRM and CRM (Goguitchaichvili et al., 2000). Oxidation of titanomagnetite and magnetite is an important phenomenon in rock magnetism. Secondary CRM may result, and if the oxidation products are the cationdeficient maghemite and titanomaghemite, the CRM may be intense, but also very unstable (Storevedt, 1970; Nishitani and Kono, 1989). At high temperatures (greater than $300^{\circ} \mathrm{C}$ ), maghemite inverts to hematite and the inversion resembles the passage of a magnetic material through its Curie point. However, upon cooling, the magnetization lost during inversion is not recoverable. On the other hand, inversion of titanomaghemite at high temperature is more complex. In- 


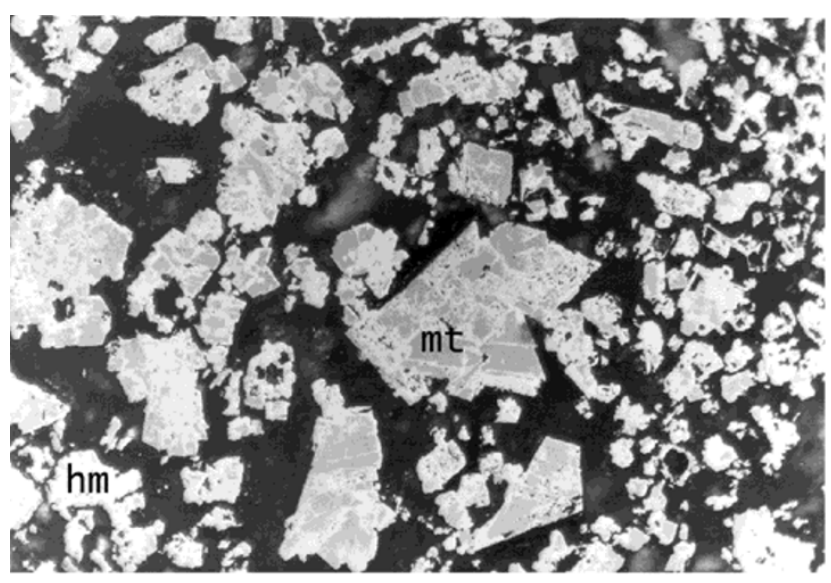

a)

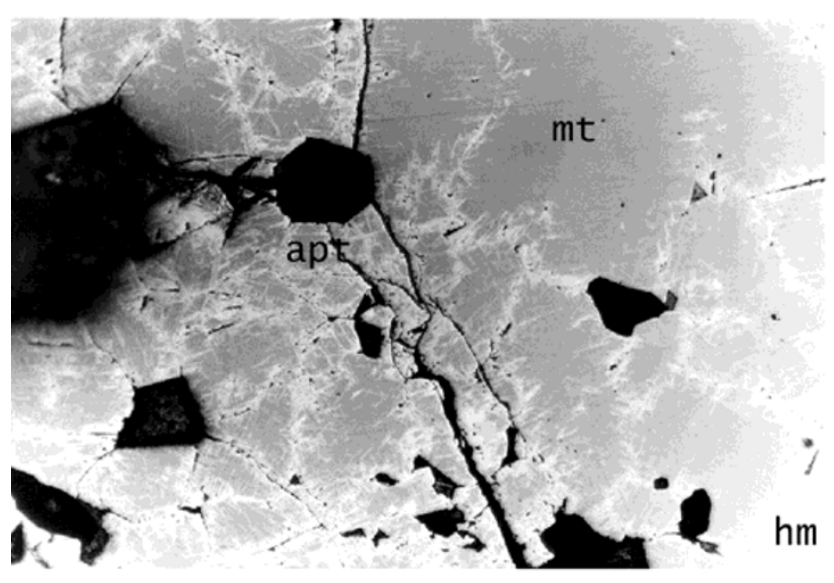

c)

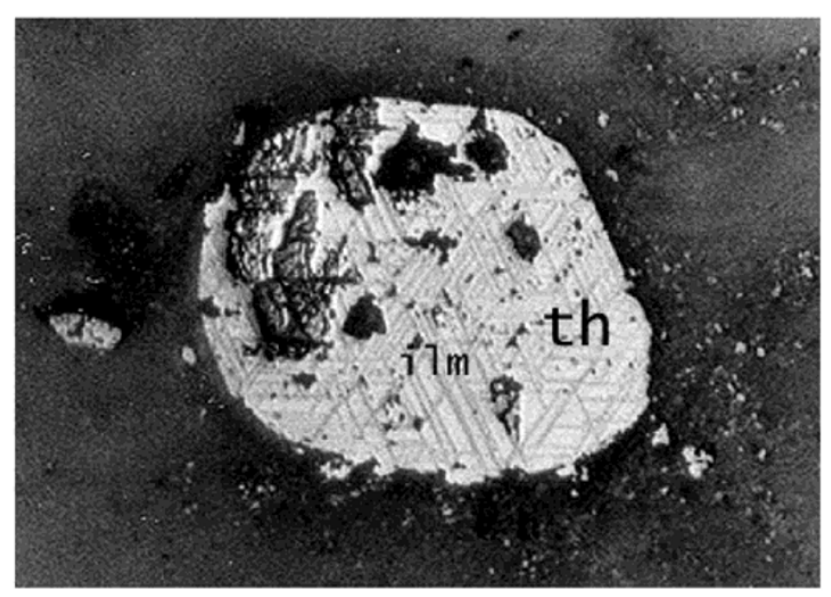

e)

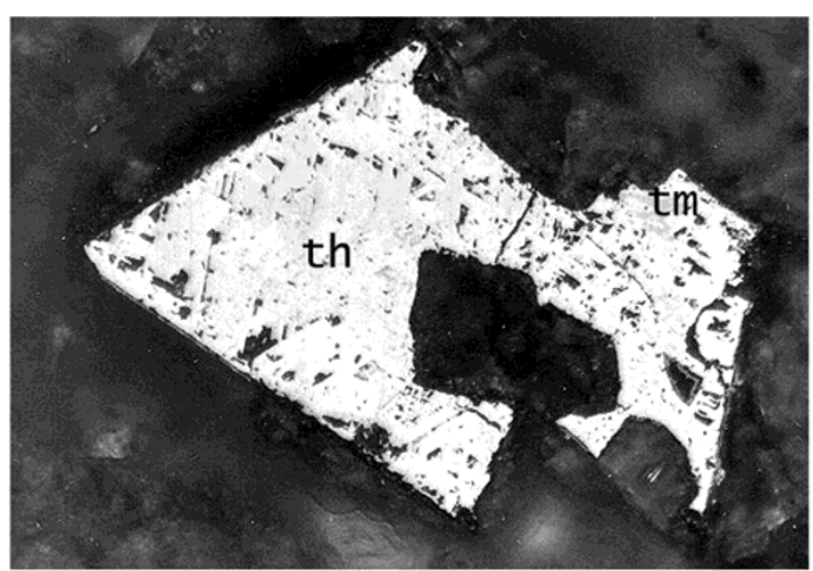

b)

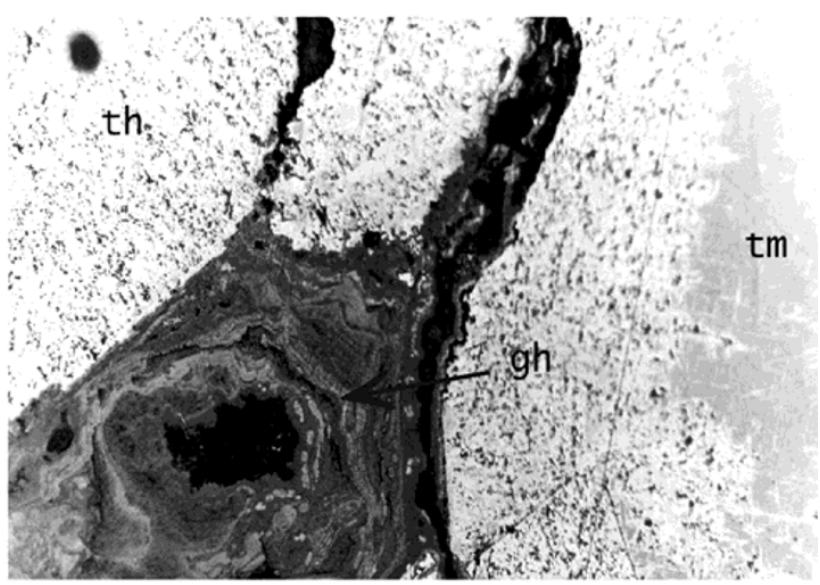

d)

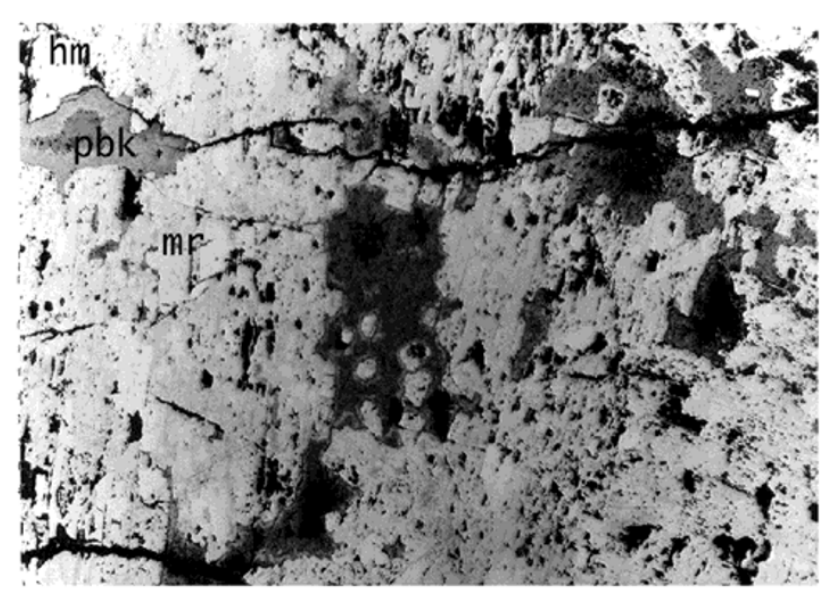

f)

Fig. 3. Photomicrographs representative of the host rocks and iron ores. General scale: $2 \mathrm{~cm}=100$ microns, except Fig. 3(b) (wide grain size $=350$ microns) and Fig. 3(e) (wide grain size $=150$ microns). Labels are as follows: $\mathrm{mt}=$ magnetite, $\mathrm{hm}=$ hematite, tm $=$ titanomagnetite, th $=$ titanohematite, apt $=$ apatite, $\mathrm{gh}=$ goethite, $\mathrm{ilm}=$ ilmenite, $\mathrm{pbk}=$ pseudobrookite, $\mathrm{mr}=$ martite.

version may produce ilmenite and magnetite, in which case magnetization grows during cooling; or it may decompose into magnetite, hematite, and either rutile or pseudobrookite (Kobayashi, 1959; Readman and O'Reilly, 1970; Ozdemir and Banerjee, 1984; Ozdemir, 1987).
Hydrothermal alteration has played an important role in Cerro de Mercado deposits, producing calcite, epidote, and some mica. The main objective of microscopic observations was to evaluate how magnetic grains were affected by hydrothermal alteration. 
Table 1. Rock magnetic and petrographic results from surficial samples of Cerro de Mercado area.

\begin{tabular}{|c|c|c|c|c|c|c|c|c|}
\hline $\begin{array}{l}\text { Site } \\
\text { No. }\end{array}$ & $n$ & Dec/Inc & $K$ & A95 & $\begin{array}{c}M_{o} \\
(\mathrm{~mA} / \mathrm{m})\end{array}$ & $\begin{array}{c}k \\
\left(10^{-3} \mathrm{SI}\right)\end{array}$ & $Q$ & Rock Type \\
\hline $\mathrm{CMBO}$ & 3 & $179.2 /-14.6$ & 63 & 16 & 2969 & 195.115 & 0.42 & $\begin{array}{l}\text { Mineralized breccia Fe-rich. I, II, III, V. } \\
\text { Pl, fd, pi, hr, qz, ap }\end{array}$ \\
\hline $\mathrm{CMB}$ & 3 & $151.6 / 31.1$ & 21 & 28 & 387 & 8.495 & 1.27 & Fe mineralized breccia. IV, V. Pl, py, ap \\
\hline CMBC & 4 & $166.4 /-18.8$ & 81 & 10 & 7546 & 58.027 & 3.62 & Skarn associated breccia. II, V. Py, qz \\
\hline $\mathrm{CMF}$ & 4 & $338.1 / 45.2$ & 5 & 46 & 7692 & 250.639 & 0.85 & $\begin{array}{l}\text { Massive Fe with quartz and apatite veins. } \\
\text { Qz, ap }\end{array}$ \\
\hline CMSC & 5 & $207.8 /-13.0$ & 13 & 22 & 4317 & 34.314 & 3.5 & Fe-mineralized skarn. IV, V. Py, qz, ap, ca \\
\hline CMP & 3 & $256.5 /-58.3$ & 17 & 31 & 7028 & 190.042 & 1.03 & Massive-Fe. Qz, ap, ca \\
\hline CMM & 4 & $143.5 /-42.5$ & 12 & 28 & 2061 & 250.296 & 0.229 & Massive-Fe. Py, qz, ca \\
\hline CME & 13 & $152.3 /-14.2$ & 1242 & 1 & 337 & 1.334 & 7.02 & $\begin{array}{l}\text { Rhyolithic vitreous tuff, partly devitrified. } \\
\mathrm{Pl} \text {, fd, hr, qz, ap }\end{array}$ \\
\hline CMI & 3 & $186.6 /-64.5$ & 27 & 24 & 715 & 0.894 & 4.67 & $\begin{array}{l}\text { Quartz-latite with opaques removilized and } \\
\text { partial devitrification. I, IV, V. Pl, py, qz, ap }\end{array}$ \\
\hline $\mathrm{CMG}$ & 5 & $359.9 /-4.9$ & 7 & 27 & 39 & 2.484 & 0.44 & $\begin{array}{l}\text { Fe with low-temperature alteration and } \\
\text { devitrification. II. Pl, qz }\end{array}$ \\
\hline CMMC & 4 & $254.9 /-56.0$ & 92 & 10 & 1745 & 43.979 & 1.1 & Massive-Fe. Qz, ap, ca \\
\hline CMSO & 5 & $129.9 /-65.7$ & 21 & 17 & 353 & 1.387 & 7.07 & Skarn. II, IV, V. Py, qz, ca \\
\hline $\mathrm{CHU}$ & 5 & $162.4 /-15.1$ & 79 & 9 & 4868 & 2.457 & 55.07 & $\begin{array}{l}\text { Rhyolithic vitreous tuff, partly devitrified. } \\
\mathrm{Pl} \text {, fd, qz, ap }\end{array}$ \\
\hline
\end{tabular}

Note: $n$, number of samples used for site mean calculation; Dec/Inc, and $M_{o}$, direction and intensity of mean characteristic remanent magnetization; $K$ and A95, confidence parameters; $k$, initial susceptibility; $Q$, Koenigsberger factor using $H=0.453$ Oe. Rock type determined from thin sections. Alteration types: I, sericitization; II, silicification; III, argilitization; IV, carbonatitization; V, epidotization. Mineralogy: pl, plagioclase; fd, feldespar; py, pyroxen; hr, hornblende; qz, quartz; ap, apatite.

\subsection{Sample description}

In general, the studied samples exhibit two generations of Fe-Ti oxides. The larger crystals (more than $30 \mu \mathrm{m}$ ), that can be easily observed are rare, whereas small crystals ( $3 \mu \mathrm{m}$ and less) are abundant in all studied samples.

Massive Fe-martite-ores (sample CMM-5) are composed of silicified magnetite and hematite and show grain-sizes up to $100 \mu \mathrm{m}$ in the quartz matrix. Regular oxidation to hematite (martitization of euhedral magnetite crystals) along both crystal margins and (111) planes indicates that hematite is not exsolving from magnetite (Fig. 3(a)). This paragenesis generally occurs at low/moderate temperatures (Haggerty, 1976), below the Curie point of magnetite and hematite. Thus, observed magnetic grains most probably carry a CRM. In a few cases (e.g., sample CMMC-3, Fig. 3(f)) pseudobrookite (dark grey) is intergrown with martite (medium grey) and hematite (light grey-white).

In a skarn sample (CMBC-5, Fig. 3(b)) a single grain of hematite, pseudomorphous after magnetite, could be observed in the silicified matrix. Less than $5 \%$ of magnetite remains, which indicates a higher intensity alteration. Figures 3(c) to 3(f) demonstrate the progressive oxidation of massive magnetite. Note the relationships between incipient martitization and crystallographic directions and fractures in the magnetite; the red internal reflections in some areas of hematite; and the reflection pleochroism of the hematite. Incipient to medium oxidation of magnetite along fractures and several alteration processes are detected (sericitization, silicification, and epidotization; a hexagonal apatite crystal appears completely replaced, Fig. 3(c)). Sample CMBO-1 is a brecciated ore Fe-rich (Fig. 3(c); magnetite, light grey; hematite, white). CMBO-4 (Fig. 3(d)) shows a massive hematite with a few relicts of titanomagnetite on the right side, and goethite developed in fractures and pores (hematite, light grey; titanomagnetite, medium grey; and goethite, dark grey).

Rhyolitic tuffs (sample CHU-1) show evidence for ilmenite, exsolved along (111) planes of the titanomagnetite host, which has since oxidized to (titano)hematite (dark grey, ilmenite; white, (titano)hematite, Fig. 3(e)). The ilmenite occurs as sheets or exsolution lenses, and has a light-grey color, with pinkish-light tones, but in the presence of magnetite it has a white color, with trellis-type textures predominantly. Sandwich and composite textures were also observed (Haggerty, 1976). These intergrowths develop typically above $600^{\circ} \mathrm{C}$; consequently, the NRM carried by these samples is a TRM.

\section{Magnetic Measurements}

In order to identify the magnetic carriers responsible for the remanent magnetization and obtain information about their magnetic stability, several rock-magnetic experiments were carried out. These experiments include: a) NRM and initial susceptibility measurements, b) Viscosity index mea- 
surements, c) Stepwise thermal demagnetization of NRM, d) Continuous susceptibility measurements, e) IRM acquisition and AF demagnetization of saturation IRM (SIRM), and f) Hysteresis experiments.

\subsection{NRM intensity, susceptibility, and Koenigsberger ratio $(Q)$}

Table 1 shows the NRM intensity $\left(M_{o}\right)$ and susceptibility (k) at room temperature, and the Koenigsberger ratio $Q=$ $M_{o} / k H$ (calculated for the present geomagnetic field in the study area). $Q$ indicates the relative importance of remanent and induced magnetization, with remanence dominant for $Q>1$. The variations in $M_{o}$ and $k$ are due to two factors, different volume contents of magnetite, and occurrence of weakly magnetic or non-magnetic phases generated at the expense of titanomagnetites during oxidation or alteration of the rocks.

Magnetic carriers in the rhyolitic tuffs present moderate to relatively high $Q$ values, indicating a predominance of pseudo-single-domain (PSD) to single-domain (SD) carriers. High $Q$ ratios may also indirectly indicate a TRM origin for the magnetization (Goguitchaichvili, 1995). As noted in the last section, the dominant carriers are Ti-poor titanomagnetites, with some deuteric oxy-exsolution products. The above observations are also valid for the skarn samples with no Fe-ore associations.

Site CMI (quartz-latite) has the lowest susceptibilities $\left(0.894 \times 10^{-3} \mathrm{SI}\right)$, related to the relatively low NRM intensities, but fairly high $Q$ ratios. Its NRMs have intermediate to high coercivity and high directional stability under AF demagnetization.

The Fe-skarn and massive iron ore samples have the highest NRM values among the various lithologies $(7.692 \mathrm{~A} / \mathrm{m}$, site CMF) and highest susceptibilities (up to $250.6 \times 10^{-3}$ SI, site CMF), with low $Q$ ratio, indicating a wide range of magnetite grain sizes carrying NRM. Bulk properties like IRM acquisition, which saturates in low fields (Fig. 4), detect only the coarse multi-domain (MD) grains, but finer PSD to SD grains must also contribute to the NRM. These finer grains probably account for the moderate coercivity, detected during AF demagnetization of IRM (Fig. 4). Although (titano) hematite was directly observed under reflected light microscopy, its magnetic signal seems to be minor.

\subsection{Viscosity index}

Determination of the viscosity index (Prévot et al., 1983) allows to estimate the capacity of a sample to acquire a viscous remanent magnetization (VRM). The viscosity index was determined for pilot samples by measuring the remanent magnetization, first after a two-week storage with the ambient field parallel to the cylindrical axis of each specimen, and then after another two-week storage in field-free space. Most of the samples showed relatively small viscosity indixes, varying between 0 and 5\%. The Cerro de Mercado samples show therefore a low capacity for acquiring VRM.

\subsection{Thermal demagnetizations}

62 samples were thermally demagnetized using a Schonstedt furnace. In general 14 temperature steps were distributed between room temperature and $680^{\circ} \mathrm{C}$ (Fig. 5). We formally calculated the directions of characteristic magnetization by means of principal component analysis (Kirschvink, 1980). These directions for the sampled sites are shown in Table 1.
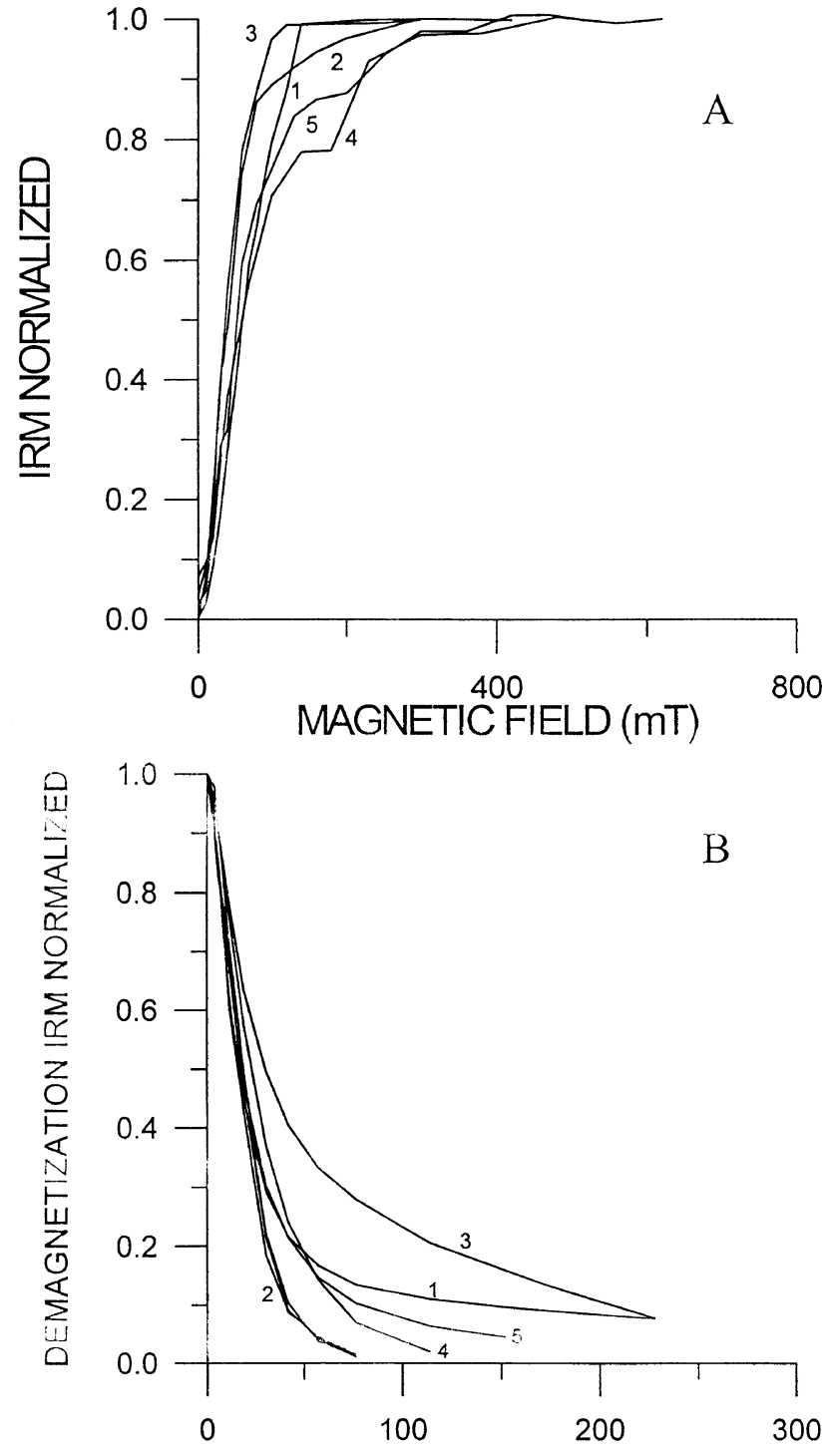

Fig. 4. a) Isothermal remanent magnetization (IRM) acquisition curves IRM intensity values are normalized to the saturating or the last value. b) Normalized intensity diagram for AF demagnetization of the IRM for different groups of rocks. 1, CMB; 2, CME; 3, CMM; 4, CMSO; 5, CMI.

Most of the units show reverse polarity directions with high within-site angular dispersion, and the site-mean directions are rather scattered. Some intermediate polarity directions (Table 1) were also found, which we attribute to chemical remagnetization, with an unblocking temperature spectrum that strongly overlaps that of the primary TRM, and not to variation of Earth's magnetic field. Alternatively, anomalous directions may result from physical movement of the ores during faulting or mining.

Vector plots (so-called Zijderveld diagrams) show different behaviour for each rock type. In general, two magnetization component were recognized (Figs. 5(a)-(b), skarn samples). The low temperature component (poorly defined) is probably due to hydrothermal alteration. The characteristic remanence is defined above $500^{\circ} \mathrm{C}$. Judging from unblocking temperature spectra it seems that both (titano)magnetite and (titano)hematite coexist. No deviation of directions was found above $580^{\circ}$, which probably attests that oxidation oc- 
A)

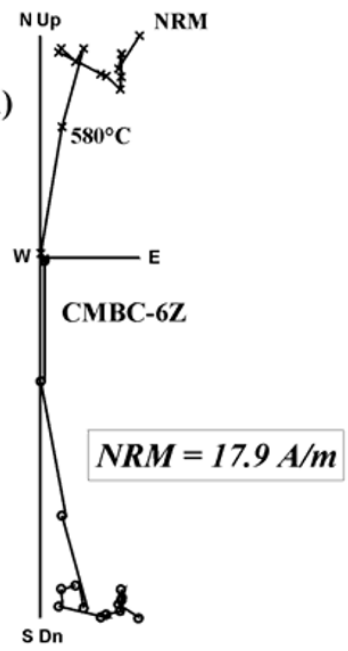

Horizontal Plane - O, Vertical Plane - X

C)

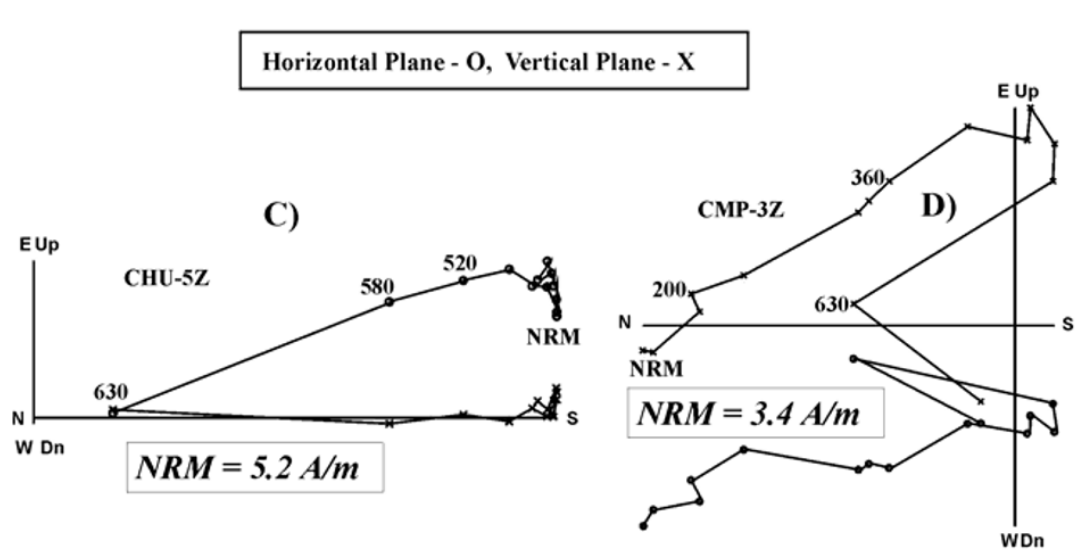

B)

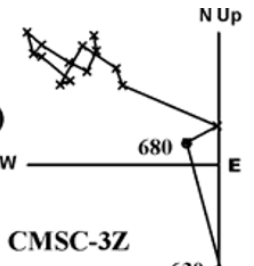

$N R M=2.4 \mathrm{~A} / \mathrm{m}$

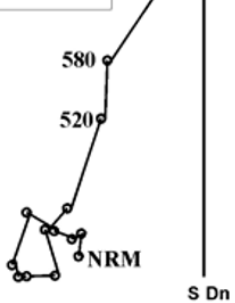

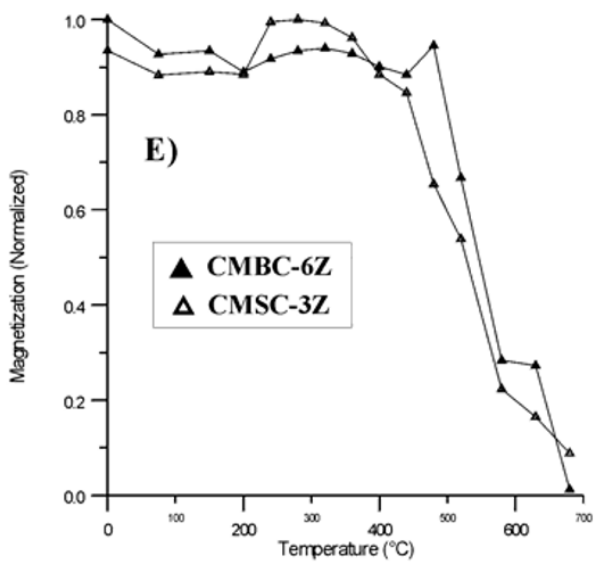

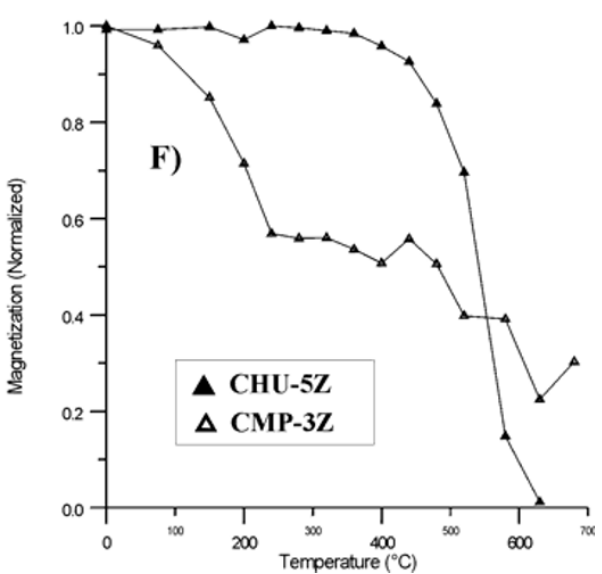

Fig. 5. Orthogonal vector plots of remanent magnetization (Zijderveld, 1967) for representative samples and corresponding NRM decay curves. The numbers refer to the temperatures in ${ }^{\circ} \mathrm{C}$. O, projections into the horizontal plane; $\mathrm{X}$, projections into the vertical plane.

curred during or soon after extrusion and cooling of the orebearing magma. The low temperature $\left(200^{\circ}-500^{\circ} \mathrm{C}\right) \mathrm{com}-$ ponent is well defined for massive-Fe samples (Fig. 5(d)), and may also correspond to chemical overprint. Alternatively, some partial thermoremanence (pTRM) could be acquired from about $300^{\circ} \mathrm{C}$ (the approximate temperature of hydrothermalism) to ambient temperature. This pTRM may only be completely removed at higher temperatures (about $500^{\circ} \mathrm{C}$ ) if magnetization is carried by PSD or MD particles (Shcherbakova et al., 1996; Goguitchaichvili et al., 1997). Rhyolitic tuffs yield reasonably linear and stable magnetic components (Fig. 5(c)). A major part of magnetization is removed above $580^{\circ} \mathrm{C}$, which probably points to the presence of magmatic (titano)magnetite as well as (titano)hematite as observed under reflected light microscopy.

\subsection{Continuous susceptibility measurements}

To study the thermal behavior of susceptibility ( $k$-T curves) in an $80 \mu \mathrm{T}$ magnetic field, one sample from each site was progressively heated up to $650^{\circ} \mathrm{C}$ and subsequently cooled down. Curie temperatures were determined following the method described by Grommé et al. (1969). Representative curves are shown in Fig. 6. In some cases $k$-T curves could not be obtained due to weak initial magnetic susceptibilities. Massive-Fe samples show an increase in susceptibility just below the Curie temperature (the Hopkinson peak), before dropping to relatively small values (Fig. 6, sample CMF-4). This behavior probably corresponds to SD or small PSD magnetic grains (Dunlop and Ozdemir, 1997). The Curie point is $580 \pm 5^{\circ} \mathrm{C}$, which indicates nearly pure magnetite as a magnetic carrier. This sample has high susceptibility, so the contribution of hematite, relative to magnetite, should be negligible. The curves suggest thermal drift of the zero level of susceptibility. Skarn samples (Fig. 6, sample CMSC-3) show also evidence of magnetite with only a minor Hopkinson peak just below the Curie point. This form is characteristic of coarse-grained PSD to MD grains. Here, again, hematite may coexist judging from susceptibility curves but its contribution is not significant (could be thermal drift). Rhyolites yielded very noisy curves (not shown). However, it can be inferred from thermal demagnetization data that nearly pure magnetite carries a major part of magnetization.

\subsection{IRM acquisition and alternating field demagnetiza- tion of SIRM}

To determine the isothermal remanent magnetization curves, previously AF demagnetized samples from all sites were subjected to magnetic fields along one axis. The curves were found quite similar in all cases (Fig. 4). Saturation is reached at relatively low field (about $200 \mathrm{mT}$ ), which points 

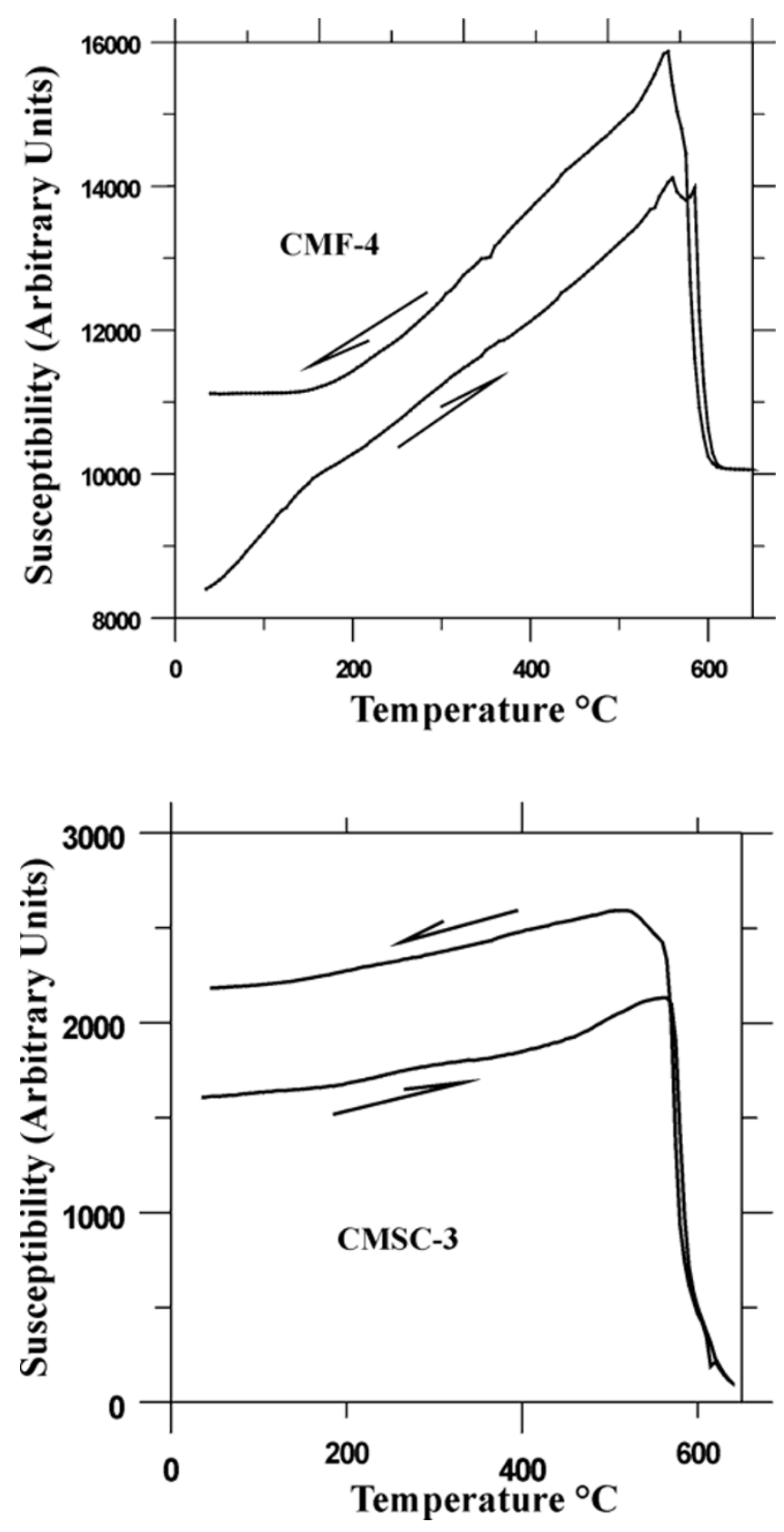

Fig. 6. $k$-low T curves showing Curie temperatures close to $580^{\circ} \mathrm{C}$. These suggest that the main carrier of magnetization is almost pure magnetite which is consistent with microscopic observations. The arrows indicate the heating and cooling curves.

to spinels as remanence carriers. Hematite, although observed directly, seems to be masked by a strong ferrimagnetic phase.

AF demagnetization curves of SIRM yield median destructive fields (MDF) in the range 20-25 mT for rhyolites, which is compatible with the coercivity of PSD particles (Dunlop, 1981). Skarns seem to have slightly higher coercivity. Feores show the highest MDFs (about $50 \mathrm{mT}$ ), which correspond to SD or 'small' PSD magnetic grains.

\subsection{Hysteresis experiments}

Hysteresis measurements at room temperature were performed on all studied units in fields up to $1 \mathrm{~T}$. The saturation remanent magnetization $\left(J_{r s}\right)$, the saturation magnetization
$\left(J_{S}\right)$, and coercive force $\left(H_{c}\right)$ were calculated after correction for the paramagnetic contribution. The coercivity of remanence $\left(H_{c r}\right)$ was determined by applying progressively increasing backfield after saturation. Some typical hysteresis plots are reported in Fig. 7. Near the origin, no potbellied and wasp-waisted behaviors (Tauxe et al., 1996) were observed, except the samples from Fe-ores. This may suggest co-existence of two magnetic phases (probably magnetite and hematite) in these units. Judging from the ratios of hysteresis parameters, it seems that almost all samples fall in PSD grain size region (Day et al., 1977). The $H_{c r} / H_{c}$ ratio ranges from 1.6 to 4.4 and $M_{r s} / M_{S}$ varies between 0.06 and 0.67 .

\section{Quantitative Interpretation of the Magnetic Anomaly}

The anomaly in the area corresponds to a large normally polarized dipole oriented almost north-south (strike $=161^{\circ}$ ) that is centered over the major mineralized bodies (Fig. 8). For modeling of the anomaly, we selected one profile (A-A') oriented almost north-south. The dipolar anomaly is characterized by a marked low and has a peak-to-peak amplitude of about $1700 \mathrm{nT}$. Quantitative interpretation was completed using a Talwani-type modeling algorithm for 2D polygonal bodies (Talwani, 1965).

We used the measured magnetic properties of the collected samples to constrain the modeling. This process was performed using several polygonal models with various combinations of magnetic properties and the best fit corresponds to a big tabular body located beneath the magnetic low together with a small body that help to fit the southern part of the profile (Fig. 9). The magnetic parameters, within the requirements for the geometry given from the borehole information and geological sections, were within the range of those measured in samples. The model (that produced an acceptable fit) required a higher susceptibility, in the order of $8(0.5) \mathrm{SI}$, than those measured in our samples, and a low to medium remanent intensity of $0.6(1.2) \mathrm{A} / \mathrm{m}$, and direction of remanence of Dec $=260^{\circ}\left(180^{\circ}\right)$, Inc $=-37^{\circ}\left(-60^{\circ}\right)$, for body 1 (body 2 ). The values of susceptibility assumed are higher than those measured in our samples, because normally it increases with depth (lower alteration). This suggest that the anomaly is generated by a major (minor) contribution of induced magnetization (remanent magnetization). The ambiguity of this process has been constrained, remaining an small degree of uncertainty in the size, depth, and form of the proposed bodies. The fitted curve show slight deviation of that observed, which is normal considering that there are many small outcrops of Fe-ore. So, we consider that our approach is representative of the main source bodies that produce the magnetic anomaly.

\section{Discussion and Conclusion}

The study of Cerro de Mercado deposits provides evidence that the iron ore was neither purely hydrothermal, nor purely volcanic in origin, as previous workers have proposed. While the ores were, magnetite-rich lava flows, they have been hydrothermally altered and intruded at an indicated crustal depth in excess of 400 meters. Thus, a rather complex sequence of events has occurred to produce the modern deposit 

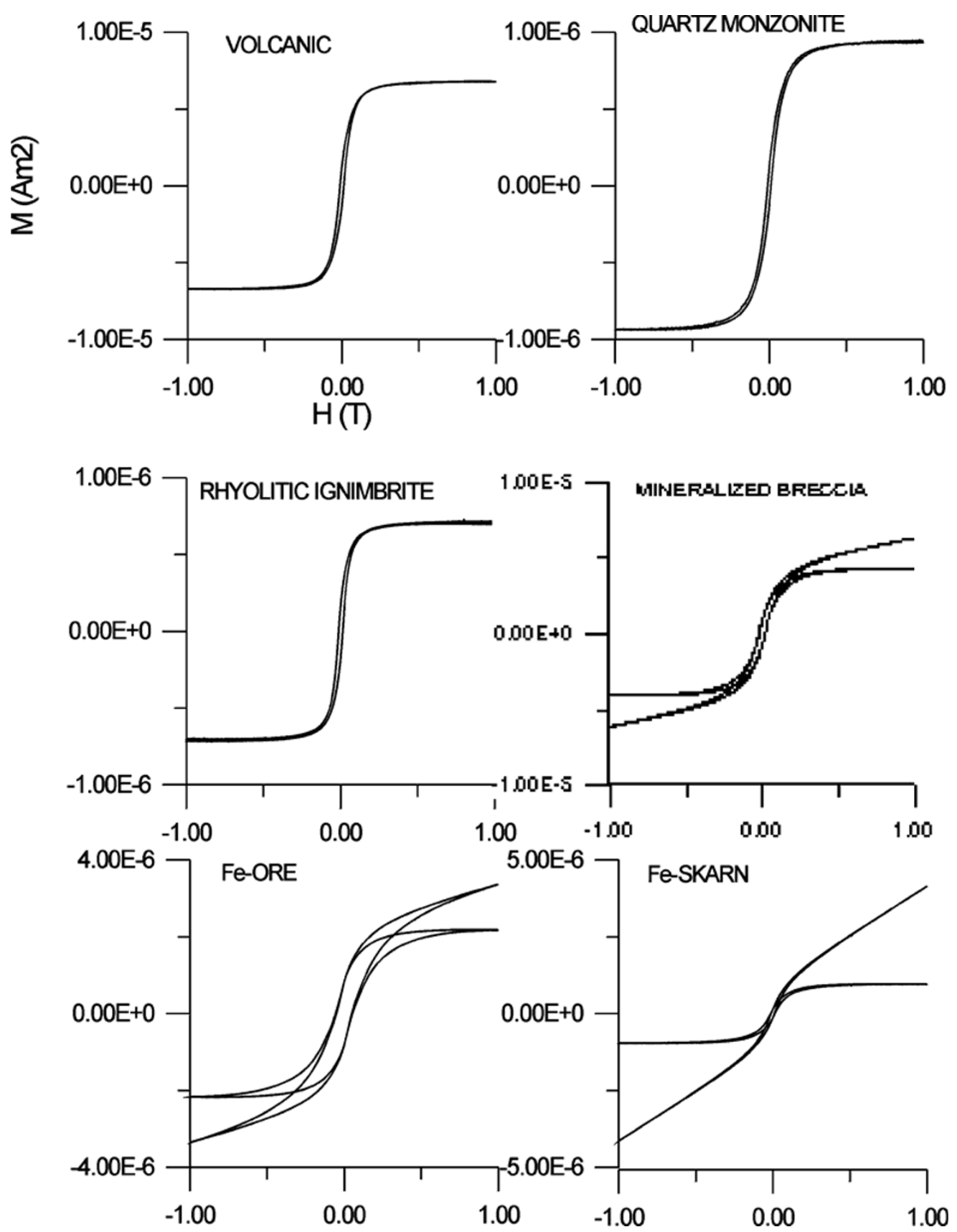

Fig. 7. Hysteresis loops (corrected for paramagnetism) for representative samples from Cerro de Mercado. Rock samples and corresponding sites are: volcanics (CHU), Quartz-monzonite (CMI), Rhyolitic ignimbrite (CME), Mineralized breccia (CMBO), Fe-ore (CMM), and Fe-skarn (CMBC).

of Cerro de Mercado.

Microscopic examination of the Cerro de Mercado ore samples indicate that they are composed basically of magnetite and (titano)hematite, with minor amounts of goethite, apatite, and quartz. Hematite results from partial martitization of original magnetite, which probably occurred during the hydrothermal event. Generally speaking, no significant differences were found in the directions of remanence carried by magnetite and hematite, which suggests that the hydrothermal event occurred soon after the extrusion and cooling. Rhyolitic samples seem not have been affected by hydrothermal alteration, since magnetic grains present evidence for high temperature deuteric oxy-exsolution. (Titano)maghemite seems to be absent from all studied sam- ples, which probably implies that the ores were oxidized at temperatures above $300^{\circ} \mathrm{C}$.

Although observed directly, (titano)hematite does not seem to represent a major contributor to total remanence. In most cases, magnetic signal belong to 'near magnetite' phase, which seems to have a wide range of PSD magnetic structure. Thus, the dominant magnetic carriers in studied ores correspond to magnetite characterized by highest values of rock magnetic properties observed in the various lithologies examined $(7.7 \mathrm{~A} / \mathrm{m})$, high magnetic susceptibilities $(0.25$ SI), 0.4 to $55.1 Q$ coefficients, and low to medium coercivity under AF demagnetization.

Figure 9 summarizes the quantitative interpretation of the observed magnetic anomaly. We used the intensity and direc- 


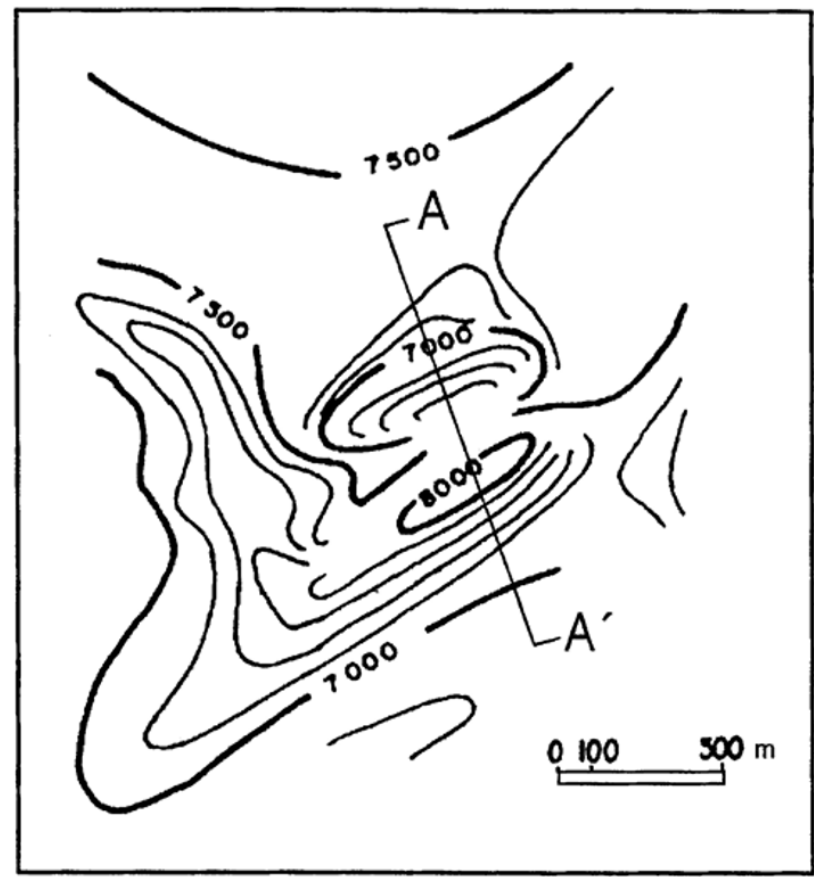

Fig. 8. Aeromagnetic anomaly map. Note the presence of a large dipolar anomaly located over the mineralized area. Location of the modeled profile is shown. Values are given in nanoteslas.
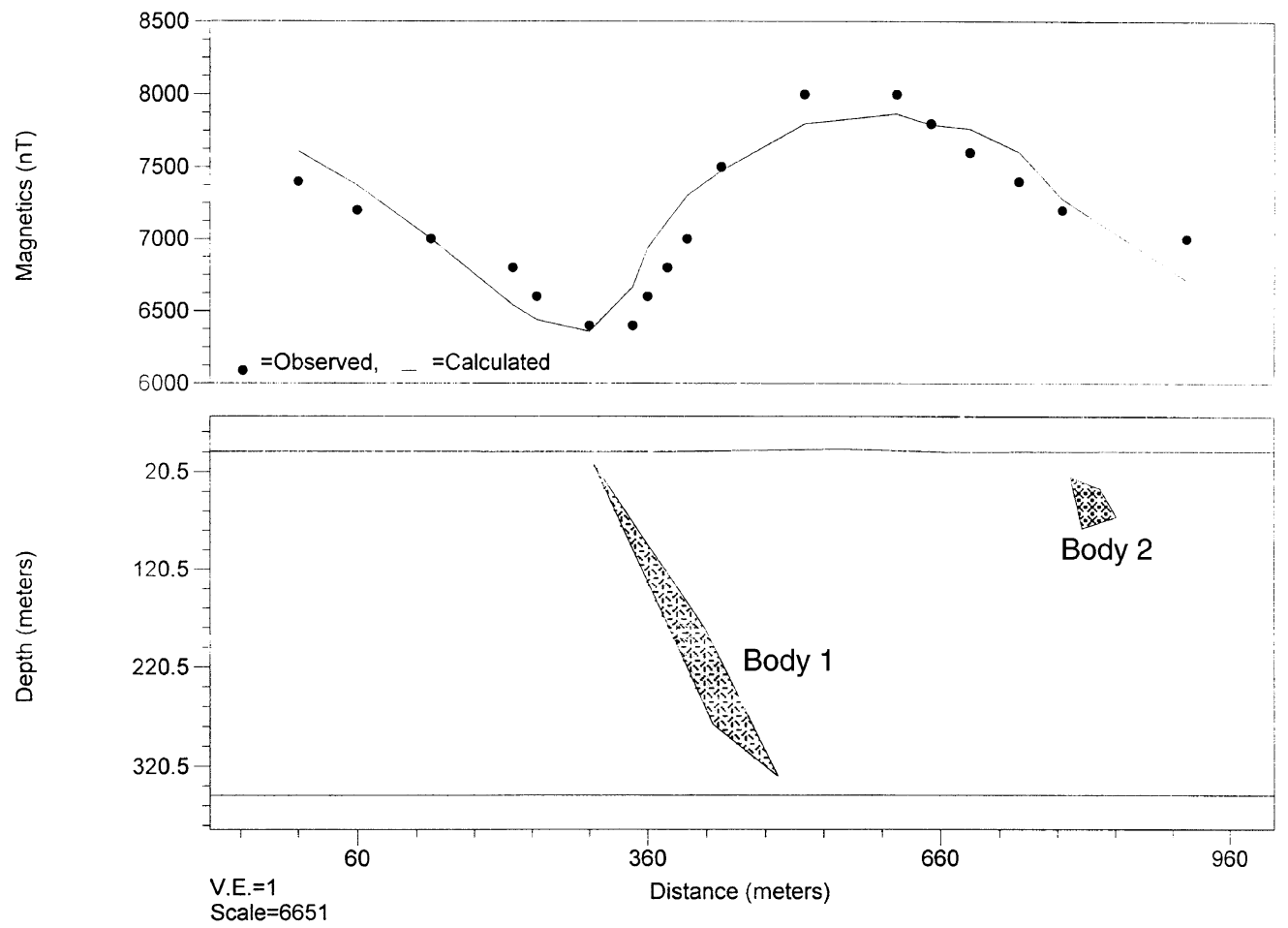

Fig. 9. Magnetic profile and quantitative model. Local geomagnetic field parameters are: declination $\mathrm{D}=9.1^{\circ}$, inclination $\mathrm{I}=51.5^{\circ}$, and total magnetic intensity $\mathrm{F}=45300 \mathrm{nT}$. We used profile stike $=161^{\circ}$ and $2 \mathrm{D}$ bodies that extend infinitely along-strike perpendicular to this profile. Magnetic data for the large body are: $\mathrm{NRM}$ declination $=260^{\circ}, \mathrm{NRM}$ inclination $=-37^{\circ}$, remanent intensity $=0.6 \mathrm{~A} / \mathrm{m}$; magnetic susceptibility $=8 \mathrm{SI}$; for the small body: NRM declination $=180^{\circ}, \mathrm{NRM}$ inclination $=-60^{\circ}$, remanent intensity $=1.2 \mathrm{~A} / \mathrm{m}$; and magnetic susceptibility $=0.5$ SI.

tion of the NRM, and the induced intensity, for the calculated anomaly. The remanence component is greater than the induced component, corresponding to $Q$ coefficients $(1.3<$ $Q<4.0$ ) greater than unity. The position and the geometry of the main magnetic source body is shown as a long body being steeply inclined $\left(75^{\circ}\right)$ to the south.

The intensity of remanence contribution is significant in the interpretation of magnetometric anomalies, particularly 
for cases where the remanent component has a direction considerably different from that of the present-day earth's magnetic field and a high intensity (Alva-Valdivia et al., 1991; Alva-Valdivia and Urrutia-Fucugauchi, 1995, 1998). For highly magnetic rocks and mineral deposits its influence is stronger, such as igneous rocks and iron-ores. The dipolar anomaly can be largely modeled by a prismatic body that closely follows the general attitude of the rock units. The proposed body is magnetite-rich with a large amplitude magnetometric anomaly.

Acknowledgments. We are grateful for the kind cooperation of the engineering staff Exploration Division of the Cerro de Mercado Company. Rock magnetic measurements were carried out by J. C. Cruz-Ocampo. This research was funded by the Instituto Panamericano de Geografia e Historia (IPGH) and CONACyT project No. 32756-T. AG gratefully acknowledges the support given by CONACyT project No. J-32727-T. JU thanks support from DGAPA project IN-102897.

\section{References}

Alva-Valdivia, L. and J. Urrutia-Fucugauchi, Rock magnetic surveys in the iron ore deposit of El Encino, Mexico, J. South Am. Earth Sci., 8, 209$220,1995$.

Alva-Valdivia, L. and J. Urrutia-Fucugauchi, Rock magnetic properties and ore microscopy of the iron ore deposit of Las truchas, Michoacan, Mexico, J. Applied Geophys., 38, 277-299, 1998.

Alva-Valdivia, L., J. Urrutia-Fucugauchi, H. Böhnel, and D. MoranZenteno, Aeromagnetic anomalies and paleomagnetism in Jalisco and Michoacan, southern Mexico continental margin, and their implications for iron-ore deposits exploration, Tectonophys., 192, 169-190, 1991.

Alva-Valdivia, L., D. J. Dunlop, and J. Urrutia-Fucugauchi, Rock magnetic properties of iron ores and host rocks from the Peña Colorada mining district, western Mexico, J. Applied Geophys., 36, 105-122, 1996.

Bookstrom, A. A., The magnetite deposits of El Romeral, Chile, Econ. Geol., 72, 1101-1130, 1977.

Clark, D. A. and P. W. Schmidt, Palaeomagnetism and magnetic anisotropy of Proterozoic banded-iron formations and iron ores of the Hamersley basin, Western Australia, Explor. Geophys., 24, 223-226, 1993.

Consejo de Recursos Minerales, Monografía Geologico-Minera del Estado de Durango, 1993.

Day, R., M. Fuller, and V. A. Schmidt, Hysteresis properties of titanomagnetites: grain size and compositional dependence, Phys. Earth Planet. Int., 13, 260-267, 1977.

Dunlop, D., The rock-magnetism of fine particles, Phys. Earth Planet. Int., 26, 1-26, 1981.

Dunlop, D. and O. Ozdemir, Rock-Magnetism, fundamentals and frontiers, Cambrige University Press, 573 pp., 1997.

Ehrlich, M., S. Sun, L. H. Scharon, and H. C. Soffel, Magnetic and paleomagnetic investigations of the Precambrian Iron Mountain deposits, Southeast Missouri, Trans. Inst. Min. Metall., Sec. B, 78, B114-B122, 1969.

Frietsch, R., On the magmatic origin of iron ores of the Kiruna type, Econ. Geol., 73, 478-485, 1978.

Goguitchaichvili, A., Inversion géomagnétique en Georgie du Sud et étude d'un exemple d'auto-inversion (Pinatubo), MSc Thesis, Univ. Montpellier, 68 pp., 1995.

Goguitchaichvili, A., D. Z. Sologashvili, M. Prévot, M. Calvo, E. S. Pavlenishvili, G. M. Maissuradze, and E. Schnepp, Paleomagnetic and rockmagnetic study of a Pliocene volcanic section in south Georgia (Caucasus), Geologie en Mijnbouw, 76, 135-143, 1997.

Goguitchaichvili, A., A. Chauvin, P. Roperch, M. Prévot, M. Vergara, and H. Moreno, Paleomagnetism of the Miocene Farellones Formation in Chile, Geophys. J. Int., 140, 357-374, 2000.

Grant, F. S., Aeromagnetics, Geology and Ore Environments, I. Magnetite in Igneous, Sedimentary and Metamorphic Rocks: an overview: Geoex- ploration, vol. 23, pp. 303-333, 1985.

Grommé, C. S., T. L. Wright, and D. L. Peck, Magnetic properties and ixidation of iron-titanium oxide minerals in Alae makaupuki lava lakes, Hawaii, J. Geophys. Res., 74, 5277-5293, 1969.

Haggerty, S. E., Oxidation of opaque mineral oxides in basalts, in Oxide Minerals (Short Course Notes), edited by D. Rumble, Mineral. Soc. Am., 3, 1-100, 1976.

Kirschvink, J. L., The least-square line and plane and analysis of palaeomagnetic data, Geophys. J. R. Astron. Soc., 62, 699-718, 1980.

Kobayashi, K., Chemical remanent magnetization of ferromagnetic minerals and its application to rock magnetism, J. Geomag. Geoelectr., 10, 99-117, 1959.

Labarthe, G., J. L. Carreon, and A. Aguillon, Cerro de Mercado, in Minas Mexicanas Tomo 5, edited by J. Ordoñez, pp. 69-91, C. AIME-SEG, 1990.

Leslie, S. L., Chemical remanent magnetization in iron ores and wall rocks of Cerro de Mercado, Durango, Mexico, Unpublished MSc Thesis, Univ. of Minnesota, 1975.

Lyons, J. I., Volcanogenic iron ore of Cerro de Mercado and its setting within the Chupaderos Caldera, Durango, Mexico, M.A. Thesis, Austin, Univ. Texas, 119 pp., 1975.

Lyons, J. I., Volcanogenic iron oxide deposits, Cerro de Mercado and vicinity, Durango, Mexico, Econ. Geol., 83, 1886-1906, 1988.

McDowell, F. W. and R. P. Keizer, Timing of mid-Tertiary volcanism in the Sierra Madre Occidental between Durango City and Mazatlan, Mexico, Geol. Soc. Am. Bull., 88, 1479-1486, 1977.

Nishitani, T. and M. Kono, Effects of low-temperature oxidation on the remanence properties of titanomagnetites, J. Geomag. Geoelectr., 41, 19-38, 1989.

Nystrom, J. O. and F. Henriquez, Magmatic features of iron ores of the Kiruna type in Chile and Sweden: ore textures and magnetite geochemistry, Econ. Geol., 89, 820-839, 1994.

Ozdemir, O., Inversion of titanomaghemites, Phys. Earth Planet. Int., 65, 125-136, 1987.

Ozdemir, O. and S. K. Banerjee, High temperature stability of maghemite, Geophys. Res. Lett., 90, 11513-11523, 1984.

Prévot, M., E. A. Mainkinen, S. Grommé, and A. Lecaille, High paleointensity of the geomagnetic field from thermomagnetic studies on rift valley pillow basalts from the middle Atlantic ridge, J. Geophys. Res., 88, 23162326, 1983.

Readman, P. W. and W. O'Reilly, The synthesis and inversion of nonstoichiometric titanomagnetites, Phys. Earth Planet. Int., 4, 121-128, 1970.

Shcherbakova, V. V., V. P. Shcherbakova, P. W. Schmidt, and M. Prévot, On the effect of low temperature demagnetizations of TRMs and pTRMs, Geophys. J. Int., 127, 379-386, 1996.

Storevedt, K. M., On remagnetization problems in paleomagnetism: further considerations, Earth Planet. Sci. Lett., 9, 409-415, 1970.

Swanson, E. R., Petrology and volcanic stratigraphy of the Durango area, Durango, Mexico, Unpublished M. A. Thesis, Univ. Texas, Austin, 1974

Symons, D. T. A., A. W. Quick, and M. Stupavsky, Magnetic and paleomagnetic characteristics of the Archean iron formation and host rocks at the Adams mine, Ontario, Ont. Geol. Surv. Misc. Pap., 98, 293-307, 1981.

Talwani, M., Computation with the help of a digital computer of magnetic anomalies caused by bodies of arbitrary shape, Geophys., 20, 797-817, 1965.

Tauxe, L., T. A. T. Mullender, and T. Pick, Pot-bellies, wasp-waists and superparamagnetism in magnetic hysteresis, J. Geophys. Res., 95, 1233712350, 1996.

Travisany, V., F. Henriquez, and J. O. Nystrom, Magnetite lava flows in the Pleito-Melon district of the Chilean iron belt, Econ. Geol., 99, 438-444, 1995.

Zijderveld, J. D. A., A.C. demagnetization of rocks: analysis of results, in Methods in Paleomagnetism, edited by D. W. Collinson, K. M. Creer, and S. K. Runcorn, Elsevier, Amsterdam.

L. M. Alva-Valdivia (e-mail: lalva@tonatiuh.igeofcu.unam.mx), A. Goguitchaichvili, J. Urrutia-Fucugauchi, C. Caballero-Miranda, and W. Vivallo 